\title{
ORAL HYDROCORTISONE THERAPY IN RHEUMATOII
ARTHRITIS
AN APPRAISAL OF GENERAL RESULTS OF PROLONGED ADMINISTRATION
}

\author{
BY \\ EDWARD W. BOLAND \\ Los Angeles, California
}

(RECEIVED FOR PUBLICATION JUNE 6, 1955)

When hydrocortisone was made available for clinical trials in the spring of 1951, three facts seemed relevant:

(1) The hormone was the principal, probably the natural, glycogenic steroid secreted by the adrenal cortex (Hechter, 1950; Hechter and others, 1951; Reich and others, 1950; Savard and others, 1952; Bush, 1951; Conn and others, 1951; Jacobsen and Pincus, 1951; Pincus, 1949; Mason, 1950).

(2) It was considerably more potent than cortisone in certain metabolic activities, as measured by laboratory experiments in animals (Ingle and Kuizenga, 1945; Pabst and others, 1947).

(3) It possessed antirheumatic activity, this having been demonstrated by Hench, Kendall, Slocumb, and Polley (1950) in a rheumatoid arthritic patient given $900 \mathrm{mg}$. of the substance over a 12-day period.

During 1951 and 1952 clinical studies were conducted to compare the therapeutic effectiveness of hydrocortisone and cortisone in patients with rheumatoid arthritis (Boland, 1952a, b, c, d; 1953a, b; 1954; Boland and Headley, 1952).

The general results of these studies may be summarized as follows:

(1) The pattern of improvement resulting from the administration of the two steroids was much the same, but smaller initial suppressive doses of hydrocortisone were required to produce corresponding inhibition of the disease manifestations.

(2) By comparing the effects of oral doses in the same patient, the antirheumatic potency of hydrocortisone was estimated to be about 50 per cent. greater than that of cortisone acetate or its free ester. In other words, the average milligram dosage of hydrocortisone needed for roughly the same degree of improvement was approximately two-thirds that of cortisone.

(3) Smaller maintenance doses of hydrocortisone were found to provide equal or superior rheumatic control, and when these were used, certain endocrine complications appeared to be fewer or less pronounced, especially psychic stimulation, salt-and-water retention, and excessive appetite.
These preliminary observations suggested that there might be a greater dissociation between the desirable anti-inflammatory action and certain un desirable physiological effects with hydrocortisones than with cortisone, and that hydrocortisone might possess a higher therapeutic index-i.e. it mights provide equal or greater benefits with smaller doses and fewer or less marked untoward reactions.

Subsequently a study of the effects of oral hydro $\frac{3}{8}$ cortisone given uninterruptedly was undertaken in a large series of patients with rheumatoid arthrifis $\vec{s}$ the relatively short-term results of which have been published (Boland, 1953b; 1954). It now seemis opportune, particularly since new synthetic analogues of the adrenocortical hormones have been dis covered, to record the results of longer-termin observations.

\section{Present Analysis}

For this report the results of prolonged oraP hydrocortisone therapy* in 150 consecutive patients: with active peripheral rheumatoid arthritis were. analysed. As statistical results are necessarily con tingent on a number of factors (including the com: position of the series in relation to disease severity. and duration, therapeutic plan and objectives method of dosage regulation, opinion as to whas constitutes satisfactory response, and judgment as to the acceptability and safety of hormonal com? plications), some of these aspects, as applied to the present study, deserve clarification.

Each patient selected for the study first had beero given a fair but unsuccessful trial on conventionat conservative measures. The majority of the patients suffered from more severe forms of the disease the arthritis was graded as severe in 39 patients (26 per cent.), moderately severe in seventy (47 pef

* The hydrocortisone (free alcohol) used for this investigation was supplied in part through the courtesy of the Medical Department, Merck and Co., Inc., Rahway, N.J. 
cent.), and moderate in 41 ( 27 per cent.). No patients with mild disease were included.

The guiding therapeutic policy was to maintain as much relief as possible with doses of hydrocortisone which could be well tolerated. Complete inhibition of the disease manifestations and total functional rehabilitation were not sought unless these could be accomplished with so-called safe levels of dosage. Submaximal improvement of about 75 to 85 per cent. of the pretreatment status was considered optimal for long-term administration. This policy was adopted because it was recognized that benefits from the hormone were only suppressive, not curative, and it had been learned from previous experience with cortisone that the incidence and severity of hormonal complications were directly related to the size of dose employed, and that their occurrence was a major factor influencing the success of long-term therapy.

Adequate or major improvement by our appraisals meant very marked or marked, and corresponded to overall improvement of approximately 75 per cent. or more as compared with the pretreatment status. It should be emphasized that improvement designated as inadequate was at least worthwhile or treatment would have been discontinued.

The following plan of dosage, consisting of three stages, was used:

(a) Initial Suppressive Doses.-As a rule, total daily dosages in the neighbourhood of the following were employed at the beginning: for severe cases, 50 to $70 \mathrm{mg}$.; for moderately severe cases, $\mathbf{4 0}$ to $\mathbf{6 0} \mathrm{mg}$.; for moderate cases, 40 to $50 \mathrm{mg}$. These amounts were continued until the clinical manifestations were satisfactorily suppressed, ordinarily for one to three weeks.

(b) Reduction of Dosage.-Dosage was then gradually lowered in stepdown fashion, reductions of $5 \mathrm{mg}$. being made every 7 to 14 days, or sometimes even more slowly. The smallest total daily amount which would control the manifestations adequately, not necessarily completely, and which could be safely tolerated, was considered as the maintenance dose.

(c) Maintenance Dosage.-Maintenance doses ordinarily ranged from 45 to $65 \mathrm{mg}$. in severe cases, 40 to $50 \mathrm{mg}$. in moderately severe cases, and 25 to $40 \mathrm{mg}$. in moderate cases. Once established, maintenance therapy was continued without interruption, the dosage being manipulated from time to time to accommodate shifts in disease activity or to control adverse reactions. Routinely the total daily requirement was taken in four divided doses, with a portion ingested at mealtimes and at bedtime. Dosage adjustments were usually made by small increases or decreases of 5 or $10 \mathrm{mg}$. at a time; large "booster" doses were rarely needed.

Minor endocrine side-effects, such as slight to moderate facial mooning or hypertrichosis, slight peripheral oedema, or irregular glycosuria, were usually looked upon as acceptable annoyances and not as reasons for stopping treatment.

Adjunctive measures such as regulated rest, avoidance of emotional stress, physiotherapy, and a well-balanced diet, relatively low in salt and with caloric restriction when indicated, were prescribed simultaneously. Salicylates were used regularly or irregularly by some patients and intra-articular injections of hydrocortisone acetate were occasionally employed in others to suppress exacerbations in one or two joints.

\section{General Results}

Statistical data were analysed in the hope of finding answers to a few general but pertinent questions:

(1) What percentage of patients who were started on hydrocortisone therapy discontinued the hormone and for what reasons? The 150 patients in this study were under observation for periods of 9 to 36 months from the beginning of therapy; more than one-third of them (37 per cent.) were followed for 2 years or longer. Treatment was stopped in 24 patients (16 per cent.), and the remaining 126 (84 per cent.) were still taking the steroid at the time of analysis. Reasons for discontinuances were as follows:

Insufficient clinical response to warrant further administration in four ( 2.7 per cent.),

Major complications attributable to the hormone in two ( $1 \cdot 3$ per cent.),

Complication unrelated to hydrocortisone in one $(0 \cdot 7$ per cent.),

Death from extraneous causes in five ( 3.3 per cent.),

Complete or nearly complete remission in twelve (8 per cent.) patients (Table).

TABLE

GENERAL DATA ON 150 CONSECUTIVE RHEUMATOID ARTHRITIC PATIENTS STARTED ON HYDROCORTISONE THERAPY (ANALYSIS 9 TO 36 MONTHS AFTER INSTITUTION OF THERAPY)

\begin{tabular}{|c|c|c|}
\hline & No. & $\%$ \\
\hline 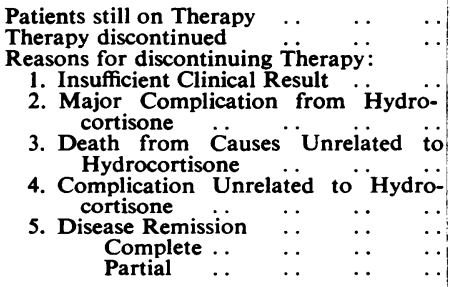 & $\begin{array}{r}126 \\
24 \\
4 \\
2 \\
5 \\
1 \\
12 \\
9 \\
3\end{array}$ & $\begin{array}{l}84 \\
16 \\
2 \cdot 7 \\
1 \cdot 3 \\
3 \cdot 3 \\
0 \cdot 7 \\
8 \\
6 \\
2\end{array}$ \\
\hline
\end{tabular}

(2) What overall results may be achieved from prolonged hydrocortisone therapy? At the time of analysis, improvement was considered to be adequate or satisfactory in 59per cent. of patients and 
less than satisfactory in 41 per cent. Inadequate degrees of improvement were noted in 62 patients for one or more reasons:

37 (62 per cent.) failed to respond satisfactorily to reasonable sized doses from the beginning of treatment,

Thirteen ( 22 per cent.) were controlled well at first, but later improvement deteriorated and responsiveness to the hormone diminished,

37 (62 per cent.) developed hormonal side-reactions which prohibited the use of optimally effective doses,

Five ( 8 per cent.) presented miscellaneous other reasons for limited improvement.

Female patients fared almost as well as male patients: inadequate improvement was recorded in 42 per cent. of the former and in 39 per cent. of the latter.

(3) What are the chief factors which influence the success of therapy? Apart from recognized correctible mistakes in management (i.e. poor selection of patients, inadequate supervision, improper dosage regulation, neglect of appropriate rest, and simple complemental measures such as avoidance of trauma,

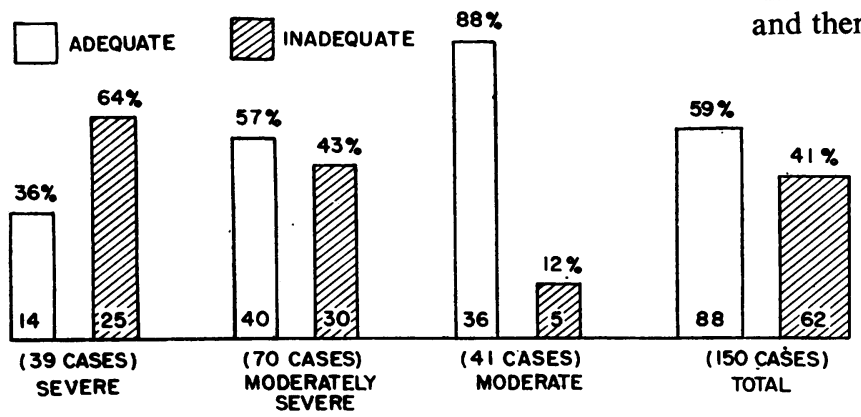

etc.), which may lead to failure, it was apparent $\frac{5}{3}$ from this study that therapeutic results bore impor- $\square$ tant relationship to two factors-the severity or activity of the disease and the duration of arthritis before treatment.

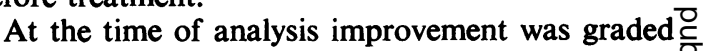
as adequate in 36 per cent. of patients with severe, $\frac{\bar{c}}{\bar{D}}$ 57 per cent. of patients with moderately severe, and $\vec{\Phi}$ 88 per cent. of patients with moderate disease $\varrho$ (Fig. 1). In general, the same problem pertained as with cortisone: for satisfactory control the more $\vec{\circ}$ severe cases all too often required excessive doses which could not be tolerated or which were con- $\vec{\rho}$ sidered unsafe for long-term administration. Surely, statistical results would have been more favourable⿳亠丷厂 had the series contained a larger percentage of $\vec{\oplus}$ moderate and some mild cases. As might bec expected, the remission rate was greater in patients ${ }_{\mathcal{E}}^{N}$ with moderate disease $\left(14.5\right.$ per cent.) than in those ${ }^{N}$ whose arthritis was moderately severe $(7 \cdot 1$ per cent. $)$ 을 or severe $(0.025$ per cent.).

Percentagewise, results were most favourable $\mathscr{\Phi}$ when the arthritis was of relatively recent origin. Interestingly, the crucial point was about 2 years, 3 and thereafter as the duration of disease lengthened, the proportion of adequate responses lessened progressively (Fig. 2). Not sir-e prising was the finding that the remissign: rate was decidedly lower in patients whoseo disease had been established more than $2 \sum_{5}$ years ( 4 per cent.) than when the duration was 2 years or less ( 22 per cent.).

(4) What deterioration of improvement? may be expected as treatment is prolonged? Analyses made at intervals during the

Fig. 1.-Improvement on adequate and inadequate dosage in relation to severity of disease.

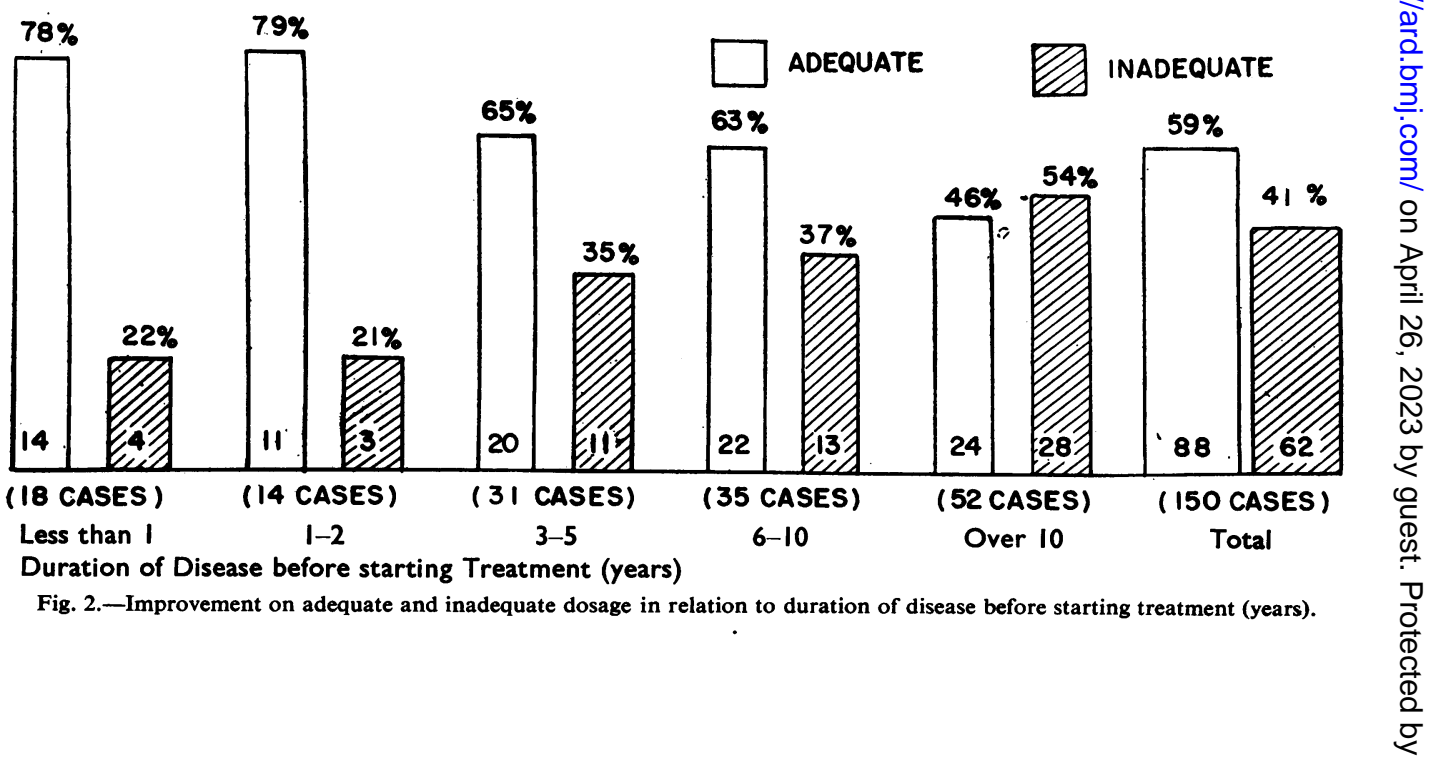




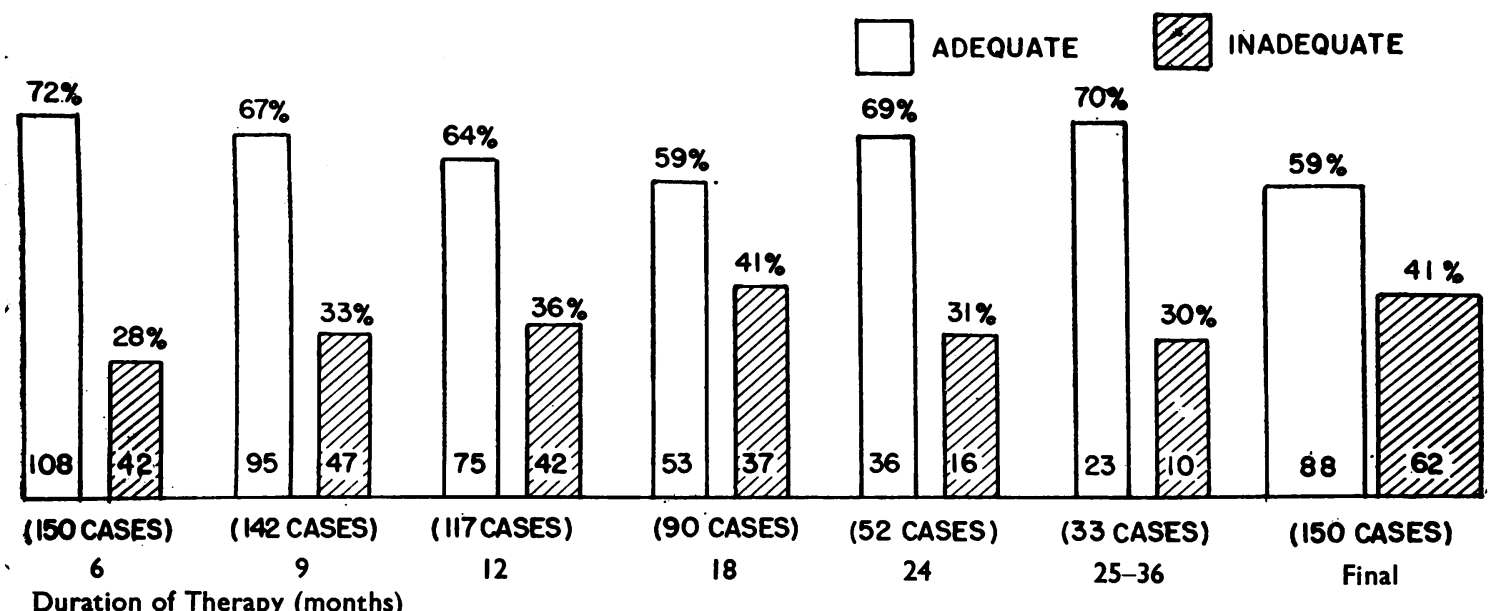

Fig. 3.-Improvement on adequate and inadequate dosage in relation to duration of therapy (months).

period of observation revealed, as anticipated, that as treatment was continued over the months, the number of patients showing adequate improvement became smaller. The figures (Fig. 3) may be confusing unless it is understood that patients were added to the series as the study progressed and that others were dropped from time to time because of remission, insufficient benefit, or other reasons. The disease was satisfactorily restrained in 72 per cent. of patients at the end of 6 months, but this percentage declined to 59 per cent. at 18 months. At 24 months and later the number demonstrating satisfactory control rose to around 70 per cent.; this is explained by the fact that the majority of patients who became unresponsive or developed unacceptable complications discontinued the hormone within a 2-year period.

(5) What influence does long-term hydrocortisone therapy have on the progress of the disease? Among the 150 patients, fifty (33 per cent.) showed evidence of disease progression during the observation period. Functional capacity was altered significantly by advancement of the arthritis in 31 patients but not in the nineteen others. The ability of steroid therapy to restrain disease progress varied indirectly with the severity or activity of the rheumatoid arthritis. Clinical evidences of progression were noted in 44 per cent. of severe cases, 34 per cent. of moderately severe cases, and 22 per cent. of moderate cases (Fig. 4). An unexpected finding in patients of this series was a lack of correlation between the frequency of disease progression and the duration of the arthritis before therapy (Fig. 5).

It is impossible to judge with full assurance what influence hydrocortisone therapy may have exerted on the natural course of the disease. There are no statistical data available with which to compare the incidence or rate of disease progression in

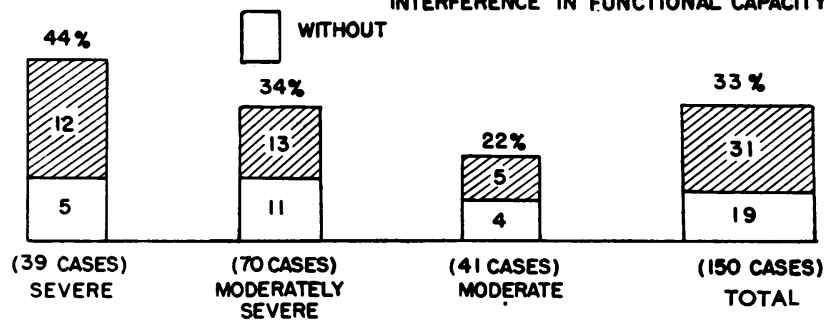

Fig. 4.-Disease progression in relation to severity of disease. 
untreated or conservatively treated patients in a series of similar composition. Furthermore, the periods of observation in the present study were relatively short ( 9 to 36 months) in respect to the average span of the disease. However, when consideration is given to the facts that the majority of patients ( 73 per cent.) suffered from severe or moderately severe forms of rheumatoid arthritis and that they had already failed to respond satisfactorily to conservative management, the incidence of disease progression seems smaller than might have been expected for a similar untreated series. The impression was gained that in cases amenable to hydrocortisone, advancement of the rheumatoid process may frequently be retarded during the period of steroid administration, and perhaps more frequently than heretofore considered.

(6) How satisfactory is hydrocortisone as a longterm treatment agent for rheumatoid arthritis? Orally administered, hydrocortisone must be regarded as a very valuable agent in the management of selected cases of rheumatoid arthritis. It promotes a high rate of immediate therapeutic response and, with relatively low maintenance doses, it is capable of providing continuous, adequate control of the rheumatic manifestations in a significant percentage of cases. Nearly 60 per cent. of patients in the present series, whose arthritis was unsuccessfully regulated by measures other than steroid therapy, were held in major improvement by the drug during observation periods ranging from 9 to 36 months. Though benefits were less than desired, varying amounts of helpful relief and enhanced functional capacity were furnished to many patients in the remaining 40 per cent.

Nevertheless, hydrocortisone is far from an ideal therapeutic agent for rheumatoid arthritis. Apart from its main deficiency, that of having suppressive rather than curative action, it has, like cortisone, many serious shortcomings. Among these may be listed:

(1) The intervention of hormonal side-effects which serve to limit dosage and often satisfactory management, especially in patients with more severe or long-established disease whose daily requirements for the drug are large;

(2) The tendency to aggravate certain co-existing pathological conditions, which contra-indicate its use;

(3) The decrease in responsiveness and improvement in some patients after prolonged administration;

(4) The frequent failure of the hormone to prevent progression of the disease during treatment.

Thus, until a cure for rheumatoid arthritis is found, there is need for an agent which, on systemic administration, will suppress the disease more successfully over long periods and in a higher pro portion of patients. A steroid with wide disparityẹ between its anti-inflammatory power and its ten- $\Rightarrow$ dency to produce unwanted effects would partially? fulfil this need. That it may be possible to prepare such compounds is suggested by a number of encouraging new developments, which have shown that modifications in the chemical structures of hydrocortisone and cortisone may attenuate those physiological actions which lead to troublesomecomplications.

\section{Summary}

The results of prolonged oral hydrocortisoneov therapy ( 9 to 36 months) in 150 consecutive patients $\stackrel{ }{\circ}$ with active peripheral rheumatoid arthritis were $\vec{c}$ analysed. The following pertinent statistical in $\omega$ formation was derived:

(1) At the time of analysis, treatment with the hormone ${ }_{0}$ had been discontinued in 24 patients (16 per cent.) for ${ }^{3}$ the following reasons: insufficient clinical response in $\vec{C}$ four (2.7 per cent.); major complications in two (1.3ळ per cent.); complications unrelated to hydrocortisone ${ }_{\mathbb{D}}$ in one $(0.7$ per cent.); death from extraneous causes in 3 five ( 3.3 per cent.); remission in twelve (8.0 per cent.).

(2) Improvement was considered as adequate in $59 \mathrm{per}$ cent. of patients and less than satisfactory in 41 per cegit. $\overrightarrow{0}$ at the time of analysis.

(3) The chief factors which influenced the success $\frac{\text { af }}{6}$ therapy were the severity or activity of the disease ando the duration of arthritis before treatment. At analysis, improvement was graded as adequate in $\mathbf{3 6}$ per cent.o with severe disease, 57 per cent. with moderately severeo̊

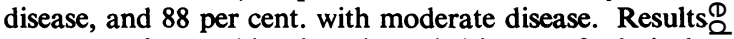
were more favourable when the arthritis was of relatively $\vec{F}$ recent origin; the crucial duration was about 2 years, 3 and thereafter as duration lengthened the proportion of adequate response lessened.

(4) As time went on, fewer patients showed adequate improvement. The disease was restrained satisfactorily in 72 per cent. at 6 months and in 59 per cent. at 18 음 months.

(5) Fifty of the 150 patients (33 per cent.) showed $_{0}^{\text {. }}$. evidence of disease progression during the observationo period. Functional capacity was not reduced significantly by advancement of the arthritis in 19 of them, 음 but was altered in the remaining 31 patients.

The following conclusions were drawn:

Although hydrocortisone is a very valuable agent in the management of selected cases of rheumatoid arthritis, it is far from an ideal suppressive agent. Like cor- $N$ tisone, it has many shortcomings, chief among which N are the intervention of hormonal side-effects, especiallyo when dosage requirements are large; the tendency to aggravate certain co-existing pathological conditions $;$ the development of unresponsiveness in some patients after prolonged administration; the failure to prevent ${ }^{+}$ disease progression in an appreciable percentage of cases. 
Thus, until a cure for rheumatoid arthritis is found, there is still need for an agent which will suppress the disease more successfully. That such a compound may be forthcoming is suggested by recent discoveries of steroids related to hydrocortisone and cortisone which possess wider dissociation the anti-inflammatory properties and the other unwanted physiological activities.

\section{REFERENCES}

Boland, E. W. (1952a). Brit. med. J., 1, 559.

(1952b). Calif. Med., 77, 1.

(1952c).J. Amer. pharm. Ass. (Pract. Pharm. ed.), 13, 540.

(1952d). J. Amer. med. Ass., 150, 1281.

(1953a). Merck Rep., 62, No. 2, 12.

(1953b). Annals of the Rheumatic Diseases, 12, 125

(1954). Med. Clin. N. Amer., 38, 337.

, and Headley, N. E. (1952). J. Amer. med. Ass., 148, 981

Bush, I. E. (1951). J. Physiol., 112, 10P.

Conn, J. W., Louis, L. H., and Fajans, S. S. (1951). Science, $113,713$.

Hechter, O. (1950). Fed. Proc., 9, 58

Zaffaroni, A., Jacobsen, R. P., Levy, H., Jeanloz, R. W., Schenker, V., and Pincus, G. (1951). Prog. Hormone Res., 6, 215 .

Hench, P. S., Kendall, E. C., Slocumb, C. H., and Polley, H. F. (1950). Arch. intern. Med., 85, 545.

Ingle, D. J., and Kuizenga, M. H. (1945). Endocrinology, 36, 218.

Jacobsen, R. P., and Pincus, G. (1951). Amer. J. Med., 10, 531.

Mason, H. L." (1950). "Urinary Excretion of Steroids during Administration of ACTH." In "Clinical ACTH Conference, Proceedings of the First Meeting", ed. J. R. Mote, p. 168. Blakiston, Philadelphia.

Pabst, M. L., Sheppard, R., and Kuizenga, M. H. (1947). Endocrinology, 41, 55.

Pincus, G. (1950). "Adrenal Cortex: Trans. First Conference, New York, Josiah Macy, Jr., Foundation, 1949", p. 47.

Reich, H., Nelson, D. H., and Zaffaroni, A. (1950). J. biol. Chem., $187,411$.

Savard, K., Kolff, W. J., and Corcoran, A. C. (1952). Endocrinology, 50, 366.

\section{Hydrocortisone par voie buccale dans l'arthrite rhumatismale \\ RÉSUMÉ}

On analysa les résultats du traitement prolongé (9 à 36 mois) à l'hydrocortisone par voie buccale de 150 malades consécutifs atteints d'arthrite rhumatismale périphérique. On obtint des données statistiques pertinentes que voici:

(1) Au temps de l'enquête, le traitement à l'hormone se trouvait interrompu chez 24 malades $(16 \%)$ pour des raisons suivantes: réponse clinique insuffisante $4(2.7 \%)$; complications majeures $2(1.3 \%)$; complications indépendantes de l'hydrocortisone $1(0.7 \%)$; morts de causes différentes $5(3.3 \%)$; remission $12(8 \%)$.

(2) A l'heure de l'enquête, l'amélioration fut considérée satisfaisante chez $59 \%$ des malades et moins que satisfaisante chez $41 \%$.

(3) L'issue du traitement dépendait de deux facteurs principaux: la sévérité ou bien l'activité de la maladie et la durée de l'arthrite avant le traitement. A l'enquête on a classé $36 \%$ des malades graves, $57 \%$ des assez graves et $88 \%$ des modérement atteints parmi les améliorés d'une manière satisfaisante. Les résultats ont été plus favorables dans l'arthrite relativement récente, avec une durée critique de deux ans à peu près, après quoi la proportion des améliorations satisfaisantes diminuait au fur et à mesure que l'ancienneté de l'arthrite augmentait.

(4) Avec le temps, le nombre d'améliorations satisfaisantes diminuait. La maladie se trouvait jugulée dans $72 \%$ des cas au bout de 6 mois et dans $59 \%$ des cas seulement au bout de 18 mois.

(5) Chez $50(33 \%)$ malades sur 150 au cours de la période sous observation on a noté des signes d'évolution de la maladie. Chez 19 d'entre eux l'aggravation de l'arthrite n'a pas entrainé de réduction appréciable de la capacité fonctionnelle, mais elle l'a altéré chez les 31 restants.

On tire des conclusions suivantes:

Bien que l'hydrocortisone soit un moyen très utile dans le traitement des cas determinés d'arthrite rhumatismale, elle est loin d'être un agent idéal de suppression. Comme la cortisone, elle a ses défauts dont le principal est le pouvoir de provoquer des réactions endocrines secondaires, surtout lorsqu'on doit administrer des doses élevées; elle tend à aggraver certains états morbides coexistants; certains malades cessant à répondre à son administration prolongée et dans un nombre appréciable des cas elle n'arrive pas à arrêter l'évolution de la maladie.

Il s'en suit, qu'à moins qu'on trouve une cure, on aura toujours besoin d'un moyen plus satisfaisant pour juguler l'arthrite rhumatismale. La découverte récente des stéroïdes apparentés à l'hydrocortisone et à la cortisone, dans lesquels le pouvoir anti-inflammatoire et certaines propriétés physiologiques indésirables se trouvent plus dissociés, semble indiquer qu'un tel moyen ne se fera pas attendre.

\section{Hidrocortisona por vía oral en la artritis reumatoide}

\section{Sumario}

Se analizaron los resultados de tratamiento prolongado (9 a 36 meses) con hidrocortisona por vía oral de 150 enfermos consecutivos con artritis reumatoide perifèrica. Los siguientes datos estadísticos pertinentes fueron obtenidos:

(1) Al tiempo del análisis, en 24 enfermos (16\%) se dejó el tratamiento hormonal por razones siguientes: respuesta clínica inadecuada, $4(2 \cdot 7 \%)$; complicaciones mayores, $2(1.3 \%)$; complicaciones independientes de la hidrocortisona, uno $(0.7 \%)$; muertos de causas ajenas, $5(3.3 \%)$; remisión, $12(8 \%)$.

(2) Al tiempo del análisis, la mejoría se juzgó satisfactoria en el $59 \%$ de los enfermes y poeo satisfactoria en los demás $41 \%$.

(3) El éxito del tratamiento dependió de dos factores principales: la severidad o la actividad de la enfermedad y la duración de la artritis antes del tratamiento. En el análisis el $36 \%$ de los enfermos graves, el $57 \%$ de los bastante graves y el $88 \%$ de los moderados fueron clasificados como satisfactoriamente mejorados. Los resultados fueron mejores en la artritis relativamente reciente, con duración crítica de dos años aproximadamente; luego, la proporción de las mejorías satisfactorias bajaba a medida que la antiqüedad de la artritis aumentaba.

(4) El número de las mejorías satisfactorias disminuía con el tiempo. La enfermedad estaba contenida en un $72 \%$ de los casos a cabo de seis meses y en un $59 \%$ solamente después de dieciocho meses.

(5) Durante el período de observación se notaron signos de evolution en 50 de los 150 enfermos. En 19 de ellos la agravación de la artritis no fué seguida de reducción apreciable de la capacidad funcional, alterada en los demás 31 .

Se llegó a las conclusiones siguientes:

Aunque la hidrocortisona sea un medio muy útil en el tratamiento de casos determinados de artritis reumatoide, le falta mucho para ser un agente represivo ideal. Como la cortisona, tiene sus defectos entre los cuales se destaca su propiedead de causar reacciones hormonales secundarias, en particular cuando se necesitan dosis elevadas; su tendencia a agravar ciertas afecciones coexistentes; algunas enfermedades dejan de responder a su administración prolongada $\mathrm{y}$, en un número apreciable de casos, no llega a contener la evolución mórbida.

Así pués, a menos de hallar una cura, un medio más satisfactorio para contener la artritis reumatoide aún nos hace falta. La reciente descubierta de esteroides relacionados con la hidrocortisona y la cortisona, en los cuales el poder anti-inflamatorio y ciertas propiedades fisiológicas indeseables están disociadas parece indicar que la descubierta de un tal medio no está lejos. 